
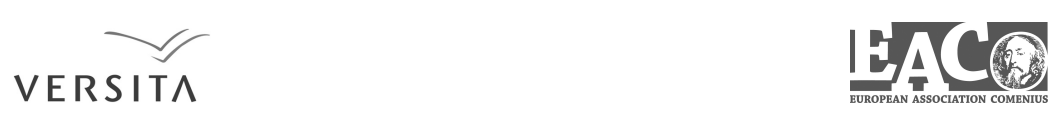

\title{
Should Non-Euro Area Countries Join the Single SUPERVISORY MECHANISM? ${ }^{1}$
}

\author{
Zsolt Darvas $^{2}$ \& Guntram B. Wolff ${ }^{3}$
}

\begin{abstract}
Irrespective of the euro crisis, a European banking union makes sense, including for non-euro area countries, because of the extent of European Union financial integration. The Single Supervisory Mechanism (SSM) is the first element of the banking union. From the point of view of non-euro countries, the draft SSM regulation as amended by the EU Council includes strong safeguards relating to decision-making, accountability, attention to financial stability in small countries and the applicability of national macroprudential measures. Non-euro countries will also have the right to leave the SSM and thereby exempt themselves from a supervisory decision. The SSM by itself cannot bring the full benefits of the banking union, but would foster financial integration, improve the supervision of cross-border banks, ensure greater consistency of supervisory practices, increase the quality of supervision, avoid competitive distortions and provide ample supervisory information. While the decision to join the SSM is made difficult by uncertainty surrounding other elements of the banking union, including possible burden sharing, we conclude that non-euro EU members should stand ready to join the SSM and be prepared for negotiations on the other elements of the banking union.
\end{abstract}

\section{Keywords}

Euro Crisis, European Banking Union, Bank Supervision, Single Supervisory Mechanism

\section{Introduction}

Following the euro-area summit of 29 June, 2012, at which European Union leaders endorsed common supervisory oversight of banks, Europe is determined to move ahead

\footnotetext{
${ }^{1}$ This paper was prepared for a hearing on The economic crisis and the development of the European Union at the Danish Parliament on 26 February 2013. The authors are grateful to colleagues both inside and outside Bruegel for comments and to Carlos de Sousa and Giuseppe Daluiso for excellent research assistance.

${ }^{2}$ Bruegel, Rue de la Charité 33, 1210 Brussels, Belgium; Corvinus University Budapest and Research Centre for Economic and Regional Studies of the Hungarian Academy of Sciences. E-mail: zsolt.darvas@bruegel.org.

${ }^{3}$ Bruegel, Rue de la Charité 33, 1210 Brussels, Belgium. E-mail: guntram.wolff@ bruegel.org.
} 
with a banking union. The decision stemmed partly from the recognition of the discrepancy between the integrated European banking market and largely national banking policies. But perhaps even more importantly, the decision was a response to increasing market pressure on several interlinked euro-area banks and sovereigns, and increasing financial fragmentation, which entailed a risk of major negative impacts on the economy of the euro-area and beyond. It is worth repeating the first sentence of the statements from the euro-area summit of 29 June, 2012: "We affirm that it is imperative to break the vicious circle between banks and sovereigns" $"$. The vicious circle has been highlighted by different researchers (e.g. Gerlach, Schulz and Wolff, 2010; Véron, 2011; Darvas, 2011; Merler and Pisani-Ferry, 2012; Angeloni and Wolff, 2012). The European banking union initiative aims to address this vicious circle, to improve the quality of banking oversight and thereby to reduce the probability of bank failures and their cost to taxpayers.

The following elements are generally seen as central to completing the banking union: common banking supervision based on a single rulebook, a single resolution mechanism, agreement on fiscal burden sharing and some degree of common deposit insurance (PisaniFerry et al, 2012). Better banking oversight would reduce the likelihood of bank failures and their cost to taxpayers while resolution equally aims to reduce costs for the taxpayer. Fiscal burden sharing is the logical complement in order to escape the vicious circle. Most of the discussion in the second half of 2012 focused on the supervisory mechanism, leading to Council agreement on the legislative proposal for the Single Supervisory Mechanism (SSM) on 12 December, 2012, (see Council, 2012, hereafter 'draft regulation') and an accompanying agreement on modifying the regulation of the European Banking Authority (EBA). With regard to the single resolution mechanism, including its fiscal backstop, the European Commission has announced its intention to publish the first proposals before summer 2013 (see Véron and Wolff, 2013, for more details). The most contentious part of the discussion certainly relates to the fiscal burden-sharing arrangements (Pisani-Ferry and Wolff, 2012).

The final design of the future banking union is still unclear. While euro-area members will be included in all elements of the banking union, the December 2012 agreement allows non-euro area EU members to participate in the SSM. Presumably, further elements of the banking union will also allow the participation of non-euro area members in certain forms ${ }^{5}$. For these countries, therefore, an important strategic question is if and when to join part or all of the emerging banking union. Once the SSM comes into being, these non-euro countries will have to decide whether or not to participate in it, without knowing the design of the other elements of the banking union. While the SSM is just a part of the banking union and cannot deliver the full benefits, it offers a number of benefits. In particular, the supervision of cross-border banks should be improved and supervisory practices should be made more consistent, thereby fostering financial integration with associated benefits.

\footnotetext{
${ }^{4}$ See http://www.consilium.europa.eu/uedocs/cms_data/docs/pressdata/en/ec/131359.pdf.

${ }^{5}$ So far only the United Kingdom has expressed very clearly the intention to stay out of the European banking union.
} 
The initial proposal for the SSM of the European Commission ${ }^{6}$ on 12 September 2012 was perceived by many non-euro area countries as not catering sufficiently for their interests. The core difficulty relates to the defined treaty base and the resulting decision-making structure. In line with the June 2012 European Council conclusions, the Commission's September 2012 proposal for a regulation (COM (2012) 511) employs as a treaty base Article 127(6) of the Treaty on the Functioning of the EU (TFEU). This article puts the European Central Bank at the centre of the mechanism. The ultimate decision-making body of the ECB is its Governing Council (Art. 129(1), TFEU), in which non-euro area countries do not have a vote. The use of this treaty base was seen by many non-euro area countries as essentially preventing them from participating in the mechanism ${ }^{7}$. In the subsequent negotiations, significant modifications were made, partly with the aim of addressing the concerns of non-euro area members. The significance of the changes is also highlighted by a change in the vocabulary. Article 2(1) of the Commission's September 2012 proposal put forward the following definition: “"participating Member State' means a Member State whose currency is the euro", while the December 2012 draft regulation changed this definition to " "participating Member State' means a Member State whose currency is the euro or a Member State whose currency is not the euro which has established a close cooperation in accordance with Article 6"8.

The European Parliament reached a deal with the Council in March 2013 and, at the time of writing, final negotiations are ongoing. The enactment of the draft regulation is expected during the summer of 2013 and the single supervisor is expected to start operating in the summer of 2014.

In this article we assess the December 2012 draft regulation (Council, 2012) from the perspective of EU states outside the euro area, and we evaluate arguments against, and in favour of, joining the SSM. The next section analyses the legal text, while section 3 discusses the arguments for and against. The last section concludes.

\section{The draft SSM regulation: key aspects for non-euro area countries}

In this section, we briefly discuss some of the key aspects of the December 2012 draft SSM regulation which are most relevant to non-euro area participating member states. We also review the safeguards for non-participating EU member states.

\footnotetext{
${ }^{6}$ COM (2012) 511. See http://ec.europa.eu/internal_market/finances/banking-union/index_en.htm, and an assessment of the Commission's proposals in Véron (2012).

${ }^{7}$ The alternative treaty base, Article 352, was not pursued and the Council had to find a compromise solution based on Article 127(6) which refers to the ECB. Article 127(6) says the following: "The Council, acting by means of regulations in accordance with a special legislative procedure, may unanimously, and after consulting the European Parliament and the European Central Bank, confer specific tasks upon the European Central Bank concerning policies relating to the prudential supervision of credit institutions and other financial institutions with the exception of insurance undertakings."

${ }^{8}$ Similarly, the title of Article 6 dealing with non-euro countries was changed from "close cooperation with the competent authorities of non participating Member States" in the September 2012 proposal of the Commission to "close cooperation with the competent authorities of participating Member States whose currency is not the euro" in the December 2012 draft regulation.
} 


\section{Legal framework}

Article 6 of the draft regulation defines the terms of cooperation of participating member states that have a currency other than the euro. The SSM is open to non-euro EU countries on the basis of "close cooperation". Close cooperation essentially requires non-euro member states that wish to join the SSM to adopt the necessary legal framework and cooperate with the ECB along the lines codified in the draft regulation. This means, in particular, that the national authorities, like those authorities within the euro area, will be bound to abide by guidelines and requests issued by the ECB and will be responsible for providing adequate information.

\section{Right to exit}

The draft regulation's Article 6 allows for the exit of non-euro area participating member states in three scenarios: 1) after three years without qualification (Article 6(6a)); 2) exclusion by the ECB in the event of major non-compliance by the authorities of the non-euro area country (Article 6(6)); and 3) expedited exit procedure at the request of the non-euro area country in the event of a major disagreement with a supervisory decision impacting the country (Article 6(6aab)). Following an exit, re-entering the SSM is possible only after three years.

\section{Decision making}

SSM draft decisions will be taken by a supervisory board created by the draft regulation. Draft decisions will be deemed adopted unless the ECB Governing Council objects within a period to be defined but less than 10 days (Article 19(3)). The supervisory board will consist of the chair, the vice chair (an ECB executive board member), four representatives from the ECB and one representative from the supervisory authority of each member state participating in the $\mathrm{SSM}^{9}$. Decisions of the supervisory board shall be taken by simple majority of its members, with every member having one vote (Article 19(2ab)), except for decisions on regulations adopted by the ECB (Article 4(3)).

This compromise considerably increases the influence of non-euro area countries over supervisory decisions, probably to the maximum that is possible under the adopted legal framework. Nevertheless, additional safeguards are provided for non-euro area countries. First, draft decisions of the supervisory board are transmitted to the member states concerned at the same time as they are transmitted to the ECB Governing Council. Whenever a non-euro area participating member state objects to a draft decision prepared by the supervisory board, the Governing Council will invite the representatives of that member state to the meeting. Appeal to the EU Court of Justice is possible. There is also the procedure (discussed above) allowing for the expedited exit of the member state (Article 6(6aab)), in which case the decision of the Governing Council will not apply to that member state.

\footnotetext{
${ }^{9}$ When the national supervisor is not the central bank, then a representative of the central bank can also participate in the supervisory board. However, when it comes to voting, they will have only one vote (Article 19(1)).
} 


\section{Accountability}

The accountability of the ECB in the exercise of its supervisory tasks is broad-based. The ECB would be accountable to the European Parliament and the Council of Ministers for the implementation of the draft regulation (Article 17). There are regular reporting requirements and the supervisory board chair needs to present the report to the European Parliament and the Eurogroup extended by those ministers of countries participating in the SSM. The chair may also be heard by the relevant committees on the execution of its tasks. Finally, the ECB is also required to answer in writing any questions raised by national parliaments, and national parliaments may invite the chair or any other member of the supervisory board for an exchange of views (Article 17aa). Overall, in terms of accountability, the draft regulation therefore puts non-euro area countries on equal terms with euro-area countries.

\section{Supervisory convergence}

One pre-requisite for the establishment of the SSM is the passing of the Capital Requirements Regulation (CRR) and the complementary fourth Capital Requirements Directive (CRD4). This is necessary so that the SSM can implement a harmonised supervisory rulebook based on the Basel III accord instead of the different national regulations that are currently in place. To ensure consistency of standards throughout the EU, the draft regulation foresees that the European Banking Authority continues to ensure supervisory convergence and consistency of supervisory outcomes. From the point of view of the rules determining banking supervision, there should be no material difference between countries in the SSM and those outside the SSM. Whether in practice there will be differences remains to be seen. It appears, however, possible that the ECB will de facto become a standard setter in supervisory practices and most member states would eventually have to apply those standards.

\section{Coverage}

As a general rule, only 'significant' financial institutions (and their subsidiaries and branches) will be directly supervised by the ECB, but the ECB will have the right to supervise any institution, if an institution is suspected of causing a significant risk to financial stability. We aim to quantify the share in total assets under direct ECB supervision in each non-euro country if it were to join the SSM (see details in the appendix). Our results (Figure 1, left column for each country) indicate that, for most non-euro area countries, participation would lead to a large share of their assets being covered, but a relatively low numbers of banks (de Sousa and Wolff (2012) document a similar result for euro-area countries). For countries outside the SSM, only branches of large banks that are headquartered in a participating member state will fall under ECB supervision, while subsidiaries remain under the supervision of national supervisors. 
Figure 1: Percent of assets falling under the SSM in case of participation and percent of assets of EU banks' subsidiaries

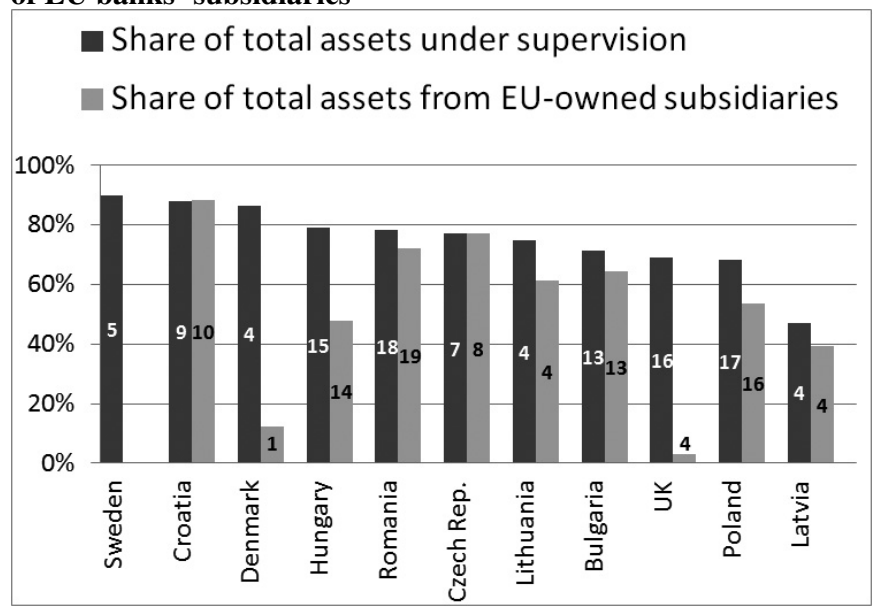

Sources: The Banker Database, ECB and Bruegel calculation

Note: The left column for each country shows the coverage of the SSM in case of participation of all EU countries, while the right column shows the share of subsidiaries of parent banks headquartered in EU countries. See Appendix 1 for details. Numbers over the bars give the number of banks.

In central and eastern Europe, where the banking systems are dominated by subsidiaries and branches of euro-area parent banks (right column of Figure 1), coverage by the SSM would mainly relate to these subsidiaries and criteria concerning the three biggest banks (see Appendix for details of criteria). In contrast, in the United Kingdom, Denmark and Sweden, the role of subsidiaries of foreign banks is minor.

Another interesting aspect in terms of coverage is the case of subsidiaries in participating member states of those banking groups that are headquartered in a non-euro area member state. For example, in tables 1-3 we look at the geographical composition of the assets of Danske Group and the Hungarian OTP Group. Danske mostly operates branches in other countries, but it has a major subsidiary in Finland, which will be covered by the SSM irrespective of Denmark's participation in the SSM, because it belongs to one of the three largest Finnish banks. Danish participation in the SSM would bring most of the group's activities under the umbrella of the ECB, including the branch in Norway. OTP Group, on the other hand, does not have a major subsidiary in any euro-area country. But OTP has several subsidiaries outside the EU and therefore, should Hungary participate in the SSM, then at least one-fifth of the total activities of the OTP Group will not be supervised by the ECB, while another fifth will depend on the SSM participation of Bulgaria, Croatia and Romania. 
Table 1: Composition of the consolidated balance sheet of Danske Group, end of 2012 $€$ billions Share

\begin{tabular}{lrr}
\hline Due from credit institutions and central banks & 15.2 & $3 \%$ \\
Repo loans & 41.2 & $9 \%$ \\
Loans and advances & 224.4 & $48 \%$ \\
Trading portfolio assets & 108.9 & $23 \%$ \\
Investment securities & 14.4 & $3 \%$ \\
Assets under insurance contracts & 32.3 & $7 \%$ \\
Other assets & 30.6 & $7 \%$ \\
\hline Total assets & $\mathbf{4 6 7 . 1}$ & $\mathbf{1 0 0 \%}$
\end{tabular}

Source: Dankse Bank (2013)

Table 2: Geographical distribution of banking activities of the Danske Group, end of 2012

\begin{tabular}{lccc} 
& $€$ billions & Share & Share in Total Assets \\
\hline Retail Banking Denmark & 127.8 & $57 \%$ & $27 \%$ \\
Retail Banking Sweden (branch) & 24.7 & $11 \%$ & $5 \%$ \\
Retail Banking Finland (subsidiary) & 20.4 & $9 \%$ & $4 \%$ \\
Retail Banking Norway (branch) & 19.0 & $8 \%$ & $4 \%$ \\
Retail Banking Ireland (branch) & 13.3 & $6 \%$ & $3 \%$ \\
Banking Activities Baltics (branches) & 2.5 & $1 \%$ & $1 \%$ \\
Other Banking Activities & 2.3 & $1 \%$ & $1 \%$ \\
Corporate \& Institutional Banking & 13.4 & $6 \%$ & $3 \%$ \\
\hline Total Banking Activities & $\mathbf{2 2 3 . 2}$ & $\mathbf{1 0 0 \%}$ & $\mathbf{4 8 \%}$
\end{tabular}

Source: Danske Bank (2013)

Table 3: Distribution of the consolidated balance sheet of the OTP Group among countries of operations, 2012Q3

\begin{tabular}{lrr} 
& $€$ billion & Share \\
\hline (a) Hungary & $\mathbf{2 1 . 3}$ & $\mathbf{5 7 \%}$ \\
(b) Euro-area countries & $\mathbf{1 . 3}$ & $\mathbf{4 \%}$ \\
Slovakia & 1.3 & $4 \%$ \\
(c) Other EU countries & $\mathbf{8 . 0}$ & $\mathbf{2 1 \%}$ \\
Bulgaria & 4.6 & $12 \%$ \\
Croatia & 1.8 & $5 \%$ \\
Romania & 1.6 & $4 \%$ \\
(d) Non-EU countries & $\mathbf{6 . 8}$ & $\mathbf{1 8 \%}$ \\
Montenegro & 0.8 & $2 \%$ \\
Serbia & 0.4 & $1 \%$ \\
Russia & 3.4 & $9 \%$ \\
Ukraine & 2.3 & $6 \%$
\end{tabular}

\begin{tabular}{lll}
\hline Consolidated & $\mathbf{3 7 . 5}$ & $\mathbf{1 0 0 \%}$
\end{tabular}

Source: OTP Bank Plc (2012) 
Table 2 shows a breakdown of the lending activities of Danske Bank, although unfortunately, a breakdown of all its activities in the countries where it operates is not available. Lending accounts for 48 percent of its total assets (Table 1). If Denmark were to remain outside the SSM, then Danske's subsidiary in Finland would be directly supervised by the ECB, because it is one of the three biggest banks in Finland. Apart from two small subsidiaries, one in Luxembourg and one in Northern Ireland (not separated in Table 2), in other euro-area countries and in the Baltic states, Danske operates branches, implying that these branches would fall under ECB supervision only if Denmark were to join the SSM.

OTP's subsidiary in Slovakia, a euro-area country, is small and therefore it will not be covered by the SSM if Hungary stays out (Table 3). But if Hungary were to join the SSM, 61 percent of OTP's activities would certainly be covered, about one-fifth of the group's total activity would be outside the jurisdiction of the SSM (activities in non-EU countries) and another one-fifth might or might not be covered, depending on Bulgaria's, Croatia's and Romania's participation in the SSM.

\section{Non-participating member states}

The draft regulation foresees that countries outside the SSM would conclude a Memorandum of Understanding describing how they will cooperate with the ECB (Article 3(4a)). This would involve regular consultations and agreement on how to manage emergency situations. The draft SSM regulation was accompanied by a regulation on changes to the EBA. Under this regulation, decisions require a double majority (a majority of both SSM participating member states and of non-participating member states), strongly improving the position of non-participating member states in EBA decisions ${ }^{10}$.

\section{Pros and cons of joining the SSM}

A number of arguments need to be carefully weighed when considering whether or not to join the SSM.

First, we consider the main concerns ${ }^{11}$ about the European Commission's September 2012 proposal, and assess the extent to which the December 2012 draft regulation addresses these issues. Here, we do not discuss the multiple questions related to the single bank resolution mechanism, the shape of which still remains largely unexplored.

\footnotetext{
${ }^{10}$ Also, the preamble to the draft regulation states that: "EBA is entrusted with developing draft technical standards and guidelines and recommendations ensuring supervisory convergence and consistency of supervisory outcomes within the Union. The ECB should not replace the exercise of these tasks by the EBA", but to adopt regulations based on the guidelines and recommendations of the EBA.

11 The source of some of these earlier worries is Zettelmeyer, Berglöf and de Haas (2012), while others emerged during our interviews with various stakeholders.
} 


\section{Inadequate inclusion of non-euro participating member states in decision making}

It was feared that the SSM would only cater for the interests of euro-area countries, while countries outside the euro area would either not be able to participate in the system, or if they would, they would not have a sufficient voice in the decisions. The Treaty's Article 127(6) provides a relatively weak basis for the involvement of non-euro area member states, as the article puts the ECB at the centre of decision making. Indeed, the final decision-making body of the ECB is the Governing Council, consisting of the ECB executive board and the central bank governors of those countries with the euro. As a consequence, final supervisory decisions will have to be passed by the Governing Council. As argued previously, within these limits, the draft regulation has arguably achieved the maximum possible decision-making power and involvement for non-euro area members.

Also, whenever a non-euro area participating member state disagrees with a draft proposal of the supervisory board and this proposal is passed by the Governing Council, or when such a member state agrees with the draft proposal, but that proposal is overturned by the Governing Council ${ }^{12}$, then the special opt-out clause for non-euro participating member states can apply, so that the member state is not bound by the decision. This is, of course, a radical decision and the draft regulation therefore foresees that, in such a situation, it is impossible to re-enter the SSM within three years. The opt-out clause caters for such concerns but comes at a significant price. In particular, it introduces significant uncertainty about the permanence of the geographical coverage of the $\mathrm{SSM}^{13}$.

Furthermore, the preamble to the draft regulation keeps the option open to adjust the treaty base of the SSM in order to enshrine the full participation of non-euro area countries $^{14}$. Overall, we would argue that non-euro area participating member states will have a sufficient voice in decision making in the steady state.

\section{Inattention to small countries}

Some feared that the ECB might devote insufficient attention to the supervision of a small country's financial system. However, this is not a concern that is in any way specific to noneuro area countries. Moreover, the draft regulation defines the clear goal of safeguarding

\footnotetext{
12 It is, however, quite unlikely that the majority on any major supervisory decision will be so thin in the supervisory board that there would be a different majority in the Governing Council.

13 This option provides non-euro area countries with a very special status in which purely national interests can, under certain conditions, be put ahead of the common interest.

14 Wolff (2012) called for a sunset clause in the regulation to force the reconsideration of the treaty base. The draft regulation's preamble now reiterates the Commission proposal (which was put forward in its Blueprint for a deep and genuine economic and monetary union) to amend Article 127(6) of the TFU to eliminate some legal constraints, such as "to enshrine a direct and irrevocable opt-in by non-euro area Member States to the SSM, beyond the model of "close cooperation", grant non-euro area Member States participating in the SSM fully equal rights in the ECB's decision-making, and go even further in the internal separation of decision making on monetary policy and on supervision." A reconsideration of the legal framework is thus not fully off the table and even German finance minister Wolfgang Schäuble argued that treaty change is needed for a proper resolution framework and that treaty change should also put non-euro area members on an equal footing in the SSM (Schäuble, 2013).
} 
financial stability both at EU level and in each participating member state. The ECB will supervise credit institutions on a consolidated basis with regard to the group, but also on an individual basis with regard to subsidiaries and branches in participating member states. While the primary focus of the SSM will be large banks, whenever there is a risk that a small bank poses a threat to financial stability, the ECB can apply supervision to this credit institution, even if it is a branch of a parent bank outside the SSM. We do not therefore see a risk that the ECB will overlook important supervisory matters in countries with few and small banks.

\section{Macroprudential tools}

Some non-euro area member states were concerned that the centralisation of macroprudential tools at the ECB would prevent them from taking appropriate macroprudential regulatory action in response to issues specific to countries outside the euro, especially with regard to capital buffers. This has been revised very significantly by the draft regulation, even though the application of Article 4a ('Macroprudential tasks and tools') to non-euro participating member states is unclear, because Article 6 only entitles the ECB to carry out tasks referred to in articles 4(1) and (2) in participating member states whose currency is not the euro and Article $4 \mathrm{a}$ is a different article.

Article $4 \mathrm{a}$ of the draft regulation grants wide-ranging rights to adopt national macroprudential regulations at national level. While the ECB can express objections to the proposed measures, the concerned national authority only has to "duly consider the ECB's reasons prior to proceeding with the decision" (Article 4a(1)), but the ECB cannot block such measures. On the other hand, the ECB can apply higher requirements for capital buffers and more stringent measures aimed at addressing systemic or macroprudential risks.

Granting the right to the ECB to apply stricter macroprudential measures in euro-area participating member states, but not in non-euro area participating member states, would be counter-intuitive and therefore we assume that this has to be a mistake in the draft regulation which will be corrected. But in any case, national authorities will have wideranging rights to apply macroprudential tools at their own discretion.

\section{Supervisory coordination failures with respect to banks with cross-border activities}

As argued by Zettelmeyer, Berglöf and De Haas (2012), a major drawback of the Commission's September 2012 proposal was not addressing the supervisory coordinator failures with respect to multinational banks, for which either the parent or the subsidiary is located outside the SSM countries. These failures arise from direct conflict of interest over how to share the burden of bank resolution, and the anticipation of such a situation during good times. The main concern of national authorities is the eventual burden on their domestic taxpayers, and they pay much less attention to the cross-border externalities of their actions.

Despite the establishment of the EBA, which aims to coordinate between home and host supervisors in the EU, several unilateral actions were adopted by national supervisors 
to ring-fence banking activities. Recently, the European Commission even had to issue a statement on 4 February, 2013, trying to limit such activities, including intra-EU capital controls and other restrictions ${ }^{15}$. While Article 1 of the draft regulation states the importance of the unity and integrity of the single market, there is not much in the draft regulation that could help to resolve such cross-border supervisory conflicts between SSM countries and those outside. One of the core points of contention will be about the eventual burden sharing - something on which this draft regulation has little to say. However, since most banks and subsidiaries established in non-euro countries are headquartered in euro-area member states (Figure 1), if non-euro countries join the SSM, this problem would have less relevance thereafter, because the ECB will be the supervisor of both the parents and the subsidiaries in participating member states.

Still, as discussed, national supervisory authorities in the SSM could apply various macroprudential measures that may also serve ring-fencing, and the ECB will not be able to block such measures.

But arguably, addressing cross-border supervisory coordination issues would be easier if both the parent and the subsidiary belong to the SSM. This suggests that those non-euro area member states in which subsidiaries of parent banks from SSM participant countries have a significant role, i.e. CEE EU members, should enter the SSM.

Similarly, since Swedish banks have significant activities in the Baltic countries and Estonia is a member of the euro area and Latvia may join the euro area in 2014, these two countries will likely be included in the SSM. We cannot rule out the possibility that Lithuania will also join the $\mathrm{SSM}^{16}$. Therefore, the suspected improvement in the supervision of cross-border banking groups by the SSM would benefit Sweden as well. Beyond these earlier concerns, a number of additional factors have to be considered.

\section{Effect on cross-border financial integration with non-participating countries}

Some observers argue that large banking groups headquartered in euro-area countries may re-consider the geographical scope of their business and may reduce their cross-border banking activities with non-SSM countries. In particular, they may reduce the activities of their subsidiaries and branches established in countries that do not participate in the SSM. This may in particular be a concern if one sees the decision to join the SSM as a clear decision to also join the forthcoming Single Resolution Mechanism. If that was to

\footnotetext{
15 While we could not find an official release, several news sites reported this statement, see e.g. Bloomberg (2013a), Reuters (2013) and Emerging Markets (2013). The statement said: "The Commission took this action because it had been made aware that, on several occasions, national bank supervisors acted independently to impose allegedly disproportionate prudential measures on national banking subsidiaries of cross-border EU banking groups. The alleged measures in question include capital controls, restrictions on intra-group transfers and lending, limiting activities of branches or prohibiting expatriation of profits. These would have the effect of 'ring-fencing' assets, which could, in practice, restrict cross-border transfers of banks' capital and potentially constrain the free flow of capital throughout the EU."

${ }^{16}$ In Lithuania, the institutions that could fall under the SSM are: Swedbank (Swedish), SEB Group (Swedish) and Snoras Bank (third largest Lithuanian bank), because these are the three largest banks, plus Danske Bank (if Denmark joins). In Latvia, Swedbank, SEB Group and Aizkraukles Banka (third biggest Latvian bank), plus Latvijas Krajbanka and Sampo Banka (if Lithuania and Denmark join, respectively) would be included.
} 
happen, it may generate economic costs for these countries and it may prove to be difficult to re-establish the currently strong cross-border financial integration, once a country has joined the SSM later.

A number of arguments need to be considered carefully in this regard. First, delaying a decision on joining the SSM increases uncertainty for the banks concerned. Banks do not know whether they will eventually fall under the joint supervision, whether they will be supervised as a group or whether subsidiaries will remain under national supervision only. This represents an important uncertainty which will justify delaying decisions on bank operations as well as investments. When bank regulation and the scrutiny of bank supervision is very different under the SSM than under national supervision, this uncertainty is compounded.

But more importantly, some of the cross-border banks are already now affected by regulatory practices relating to cross-border liquidity and capital operations. Indeed, a number of home supervisors tried to ring-fence banking activities inside the home country during the crisis, as we discussed in the previous sub-section. Even though one of the goals of the draft regulation is to preserve the integrity of the single market, this risk will remain, and in particular, the home supervisor of the parent bank may discriminate against nonparticipating member states. It remains to be seen to what extent the ECB will be able and willing to challenge the currently reported ring-fencing of banking activities.

At the same time, there are also factors suggesting that participation in the SSM, or the lack of it, may not be a key factor influencing the cross-border investment decisions of major banking groups. Banking groups made strategic decisions to engage in activities outside the country of their headquarters. In non-euro area member states in central and eastern Europe (CEE), banking was much more profitable than in EU15 countries before the crisis (Figure 2 ; starting point of the arrows $)^{17}$. While CEE economic growth rates will likely be smaller compared to pre-crisis growth rates, and economic growth is not the only determinant of bank profitability, these countries continue to have a brighter economic outlook than euro-area countries, according to medium-term forecasts ${ }^{18}$. Therefore, banking in these countries will likely remain more profitable than banking in euro-area countries. Clearly, major euro-area banking groups have started to reduce their exposure to the region, but most likely because either their exposure has grown too high or because they faced serious capital and liquidity needs in their home countries or regulatory pressure with similar effects. These latter considerations may remain and therefore their exposure to the region may be reduced further.

Figure 2 shows that the exposure of international banks to the CEE countries generally declined during the crisis while profitability also declined. The exposures of foreign banks

\footnotetext{
${ }^{17}$ During the crisis, return on equity was highly negative in the three Baltic counties that went through unsustainable credit booms before the crisis and an extreme bust and economic hardship during the crisis. Bank profitability also turned negative in Hungary by 2011 due to unusually high bank taxes and other measures.

${ }^{18}$ Bank profitability depends on many factors, such as the composition and the risk profile of assets, competition, bank taxes, etc. But faster economic growth helps bank profitability by reducing the share of non-performing loans and by offering more scope for expansion of banking activities. The simple correlation coefficient between pre-crisis GDP growth and return on equity is 0.50 during 2003-2007 and 0.62 during 2008-2011 for 26 EU countries (current EU27 minus Cyprus and Malta due to lack of data, plus Croatia).
} 
to Denmark and Sweden have not declined from 2008Q3 to 2012Q3. The change in exposure to CEE countries from 2008Q3 to 2011Q3 was greater when (a) the exposure was greater in 2008Q3 and (b) bank profitability declined significantly from 2008-2011. Foreign banks may be more selective in cross-border investments, but we see little incentive to reduce the exposure to, e.g. the Czech Republic and Poland, two countries in which the banking business remained highly profitable during the crisis and the exposure of foreign banks is not too high. In Denmark and Sweden, banking also generated sizeable returns: better than in all other EU15 countries indicated on the right panel of Figure 2.

Also, supervisory differences might not be a major concern. Major banking groups have developed their CEE subsidiaries under the supervision of national authorities and hence the absence of change in the supervisor should not immediately imply a change in their strategic engagements. It can be assumed that the headquarters anyway have strong controls over their subsidiaries. Too-stringent national macro-prudential tools limiting business opportunities may be implemented under the SSM as well as outside of it.

Figure 2: Return on equity of banks and the change in foreign banks' exposure to the domestic economy from $2008 \mathrm{Q3}$ to $2012 \mathrm{Q3}$

Central and eastern Europe

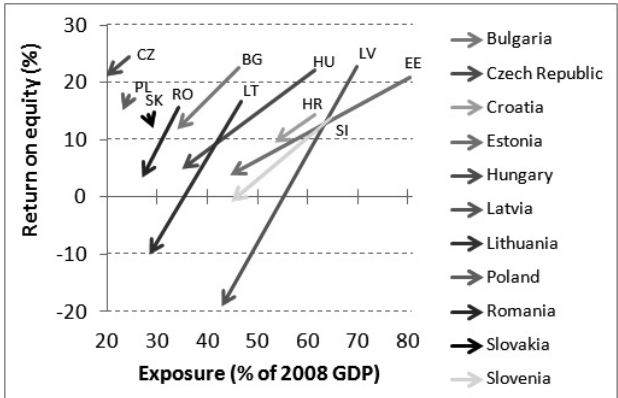

EU members before 2004

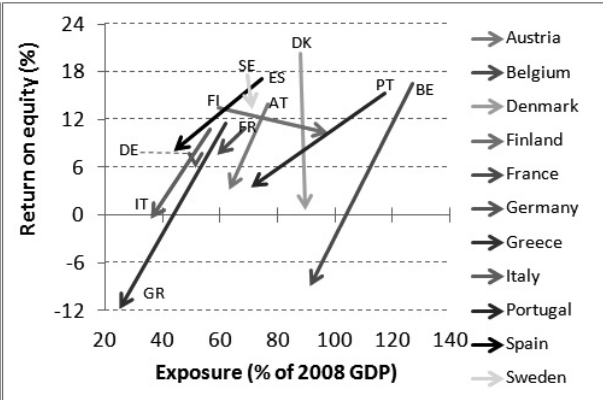

Source: Bruegel calculations using IMF Financial Soundness Indicator tables and BIS data

Note: the starting coordinate of an arrow is the exposure of BIS reporting banks (i.e. all banks in the world, not just euro-area banks) in 2008Q3 as a percentage of 2008 GDP of the host country on the horizontal axis and the average return on equity during 2003-2007 on the vertical axis. The end coordinate of an arrow is the exposure in $2012 \mathrm{Q} 3$ on the horizontal axis and the average return on equity during 2008-2011 on the vertical axis. The 2012Q3 exposure is expressed again as a percentage of 2008 GDP, in order not to confuse changes in the exposure with changes in GDP, and the 2012Q3 exposure was calculated on an exchange rate-adjusted basis so that exchange rate changes do not influence the reported magnitude of the change in exposure. Data for six EU countries are not reported due to very high values. In these countries, the exposure declined from 2008Q3 to 2011Q3: in Cyprus from 271 percent to 242 percent; in Ireland from 486 percent to 299 percent; in Luxembourg from 1,778 percent to 1,748 percent; in Malta from 546 percent to 450 percent; in the Netherlands from 177 percent to 143 percent; and in the United Kingdom from 202 percent to 179 percent (all are expressed as a \% of 2008 GDP and are based on exchange-rate adjusted changes). 
Overall, the immediate risk related to reducing the activities of subsidiaries of major banking groups established in non-participating countries may not be very high, but uncertainty, including about discriminatory measures against non-participating member states by the home supervisor of the parent bank, could limit the activities of large financial groups in non-participating member states (and also in non-EU countries).

\section{Competitive disadvantage of banks not owned by a parent bank headquartered in an SSM country}

When a country remains outside the SSM, then domestically-owned banks and those banks that do not have a parent bank in an SSM participating member state may face a competitive disadvantage. If supervision by the ECB is regarded as an important safeguard in the assessment of the soundness of banks, then staying out may imply higher financing costs: the cost of wholesale funding may be relatively higher and the depositors may also require a higher interest rate. While it is difficult to assess the risk and the magnitude of such competitive disadvantages, they call for membership of the SSM.

\section{Implicit obligation to join other elements of the banking union after SSM membership}

Clearly, there is uncertainty about the next steps for the banking union, and belonging to the SSM may imply an obligation to join other elements of the banking union when they are adopted. More specifically, Point 11 of the 14 December 2012 European Council conclusions foresees that the Single Resolution Mechanism (SRM) will apply to member states participating in the SSM (see European Council, 2012). However, the draft regulation itself does not include a legal obligation for SSM members to join the SRM when it is enacted and therefore, in principle, a non-euro area SSM participating member may decide to opt out of the SRM.

The experience with the negotiations for the SSM showed that the interests of non-euro area member states were considered to perhaps the greatest possible extent allowed by the TFEU. As in the case of the SSM, the next step in the banking union, the SRM, will be agreed on by the co-legislators, to which the non-euro members are a full party. We do not see how non-euro countries would have a smaller impact on policy choices than euroarea members. At the same time, non-euro area countries are not included in important debates, in particular those relating to the European Stability Mechanism (ESM). But SSM membership would not make a material difference in these debates.

On the whole, we do not believe that any automaticity in joining further elements of the banking union should be assumed and this should not be a central argument for not joining the SSM.

\section{Contribution to the shaping of the practical operation of the SSM}

The ECB Governing Council and the supervisory board will have to set the rules for the practical operation of the SSM. This will be done at an early stage and will likely shape the effectiveness and inclusiveness of the new mechanism in a fundamental way. While 
according to the draft regulation, non-euro member states will be members only if this decision is published in the Official Journal of the European Union (Article 6(4) of the draft regulation) and therefore most likely they can join formally only after the system has been set up, a clear and early signal to join the SSM is likely to increase the voice of non-euro member states in shaping the modalities. This argument therefore calls for an early indication of the intention to join, even though the modalities must be in line with the draft technical standards and guidelines and recommendations prepared by the EBA.

\section{Access to supervisory information}

Non-participating EU member states will sign a memorandum of understanding with the ECB on cooperation during good times (i.e. consultations relating to decisions of the ECB having effect on subsidiaries and branches established in the member state) and cooperation in emergency situations. This may improve the flow of information related to supervisory matters from the SSM towards non-participating countries, but undoubtedly, participating member states will have full access to supervisory information. This would be especially valuable for countries in which several subsidiaries and branches of euroarea banking groups are established, i.e. the CEE members of the EU. But the authorities of other countries, such as Denmark and Sweden, would also benefit from the access to supervisory information concerning financial institutions covered by the SSM. Therefore, access to supervisory information weighs positively on the decision to join the SSM.

\section{Conclusion}

The European banking union project makes sense irrespective of the euro crisis. It also makes sense for non-euro area countries. In a financially-integrated area, like the European Union, differences in national banking policies can tilt the playing field and lead to suboptimal banking and supervisory decisions. The pre-crisis experience with exuberant banking in some countries, but not in others, and the resulting banking fragility during the crisis and its cross-country implications, further underline the need for more centralisation of banking policies at the EU level.

This article has reviewed the December 2012 draft regulation for the first element of the banking union, the establishment of a Single Supervisory Mechanism, from the point of view of non-euro area countries. While the treaty base provides a relatively narrow basis for the involvement of non-euro area countries, the achieved compromise provides strong safeguards to protect the interests of non-euro area countries:

- They will have the same voice as euro-area member states in the ECB supervisory board;

- They will have the right to exit and therefore exempt themselves from a supervisory decision;

- With regard to its supervisory tasks, the ECB will be accountable to the European Parliament and the Council of Ministers (i.e. EU institutions);

- The supervisory board will report regularly to the Eurogroup, extended to include the ministers of non-euro participating member states; 
- The ECB will have to answer in writing questions from national parliaments, and members of the supervisory board can be invited by national parliaments;

- The draft regulation requires the ECB to pay as much attention to financial stability in each member state as to the financial stability of the EU, and while the focus of the SSM will be on large banks, the ECB will have the right to exercise supervisory power with respect to small banks as well if they are suspected to posing a threat to financial stability. Moreover, the ECB has overall responsibility for the SSM;

- Macroprudential tools will remain in the hands of national authorities of participating member states.

On its own, the SSM would not bring the full benefits of a banking union, but it could deliver a number of advantages:

- Fostering financial integration with associated benefits;

- Improving the supervision of cross-border banks;

- Possibly improving the quality of banking oversight;

- Ensuring greater consistency of supervisory practices;

- Avoiding eventual competitive distortions;

- Providing supervisory information on all financial institutions participating in the SSM.

For different countries outside the euro area, different aspects could be more valuable. For example, for Denmark, a country that hosts only few subsidiaries and branches of foreign banks, but in which banking supervision is thought to be one of the strictest, the main benefit could be greater consistency of supervisory practices and the avoidance of competitive distortions. According to some stakeholders, certain Danish and Swedish supervisory practices are rather different, putting Danish banks at a competitive disadvantage relative to Swedish banks. Therefore joint Danish/Swedish participation in the SSM could level the playing field. Denmark would also benefit from the improved supervision of cross-border banks, because the biggest Danish bank, Danske Bank, has a major subsidiary in Finland. In addition, SSM participation will be a precondition for participation in the Single Resolution Mechanism, once agreed. Currently, the strict bail-in clause of the Danish bank resolution legislation has led to a downgrade of Danish banks by two notches and a corresponding increase in bank borrowing costs, a development acknowledged by Danish central bank Governor Lars Rohde in his speech at the parliamentary hearing for which this article was originally prepared (Bloomberg, 2013a; see also slide 5 of Danske Bank, 2012). While the SRM will also likely have important elements of bail-in and other possibilities to impose losses on bank creditors, this would apply to all members of the SRM and thereby prevent competitive distortions ${ }^{19}$.

In CEE countries, where the banking system is dominated by foreign banks, fostering financial integration, getting supervisory information on parent banks and improving the supervision of cross-border banking groups could also be of major relevance. Also,

${ }^{19}$ For Denmark, the incorporation of tough bail-in rules in the SRM (similar to the current Danish bank resolution legislation) will be essential (see Bloomberg, 2013b and 2013c). 
a number of CEE countries went through unsustainable credit booms before the crisis, mostly accompanied by foreign currency lending, which has had major repercussions. Addressing national credit booms through national supervisory action only is difficult, since banks can exploit supervisory arbitrage. A single supervisory mechanism is more suitable for addressing such credit booms. The SSM will also be able to address more easily previous possibilities of regulatory arbitrage in which banks could turn subsidiaries into branches and vice versa to benefit from different regulatory requirements.

Making a decision on joining the SSM is made more difficult by the uncertainty concerning the design of other elements of the banking union. At the same time, little is known at the moment about the eventual burden-sharing element of the banking union. Stakeholders in some countries fear that their taxpayers will have to bail out foreign banks, while others fear that an eventual lack of a proper burden-sharing agreement would not break the vicious circle between banks and sovereigns, and therefore the full benefits of the banking union cannot be attained. In particular, lack of ESM participation of non-euro area member states that joined the banking union is a major concern. Yet we see no reason why the ESM Treaty could not be changed later to include non-euro area members of the banking union (only for the banking resolution task of the ESM, not for the lending to euro-area sovereigns task). Also, if the fiscal backstop will be organised differently from the ESM, non-euro area members could be included on equal footing with euro-area members.

We agree that the full benefits of the banking union can be achieved only with a coherent system that also involves some burden sharing together with very stringent resolution tools. However, improved supervision and consistent resolution among participating member states should reduce the probability of the need for cross-border burden sharing. And even if such a proper agreement on burden sharing is not on the horizon at the moment, the SSM in itself would bring a number of benefits for all EU countries outside the euro area and the main contours of the SRM will also be revealed in the coming months. We therefore conclude that non-euro area countries should stand ready to join the SSM and should be prepared for constructive negotiations on the SRM.

\section{References}

Angeloni, Ch., Wolff, G. B. (2012). Are Banks Affected by their Holdings of Sovereign Debt? Bruegel Working Paper, 2012/07.

Bloomberg (2013a). EU Warns of 'Disproportionate' Crackdown on Cross-Border Banking. Retrieved February 4, 2013 from http://www.bloomberg.com/news/2013-02-04/euwarns-of-disproportionate-crackdown-on-cross-border-banking.html.

Bloomberg (2013b). Bail-Ins Key in Ending Vicious EU Bank Circle, Rohde Says'. Retrieved February 26, 2013 from http://www.bloomberg.com/news/2013-02-26/bail-inscrucial-in-ending-vicious-eu-bank-circle-rohde-says.html.

Bloomberg (2013c). Denmark Fights to Push Tougher Bail-In Rules in Europe. Retrieved March 4, 2013 from http://www.bloomberg.com/news/2013-03-04/denmark-fightsto-push-tougher-bail-in-rules-in-europe.html. 
Council (2012). Proposal for a Council Regulation conferring specific tasks on the European Central Bank concerning policies relating to the prudential supervision of credit institutions (SSM draft regulation). Brussels: Council of the European Union. Available at http://register.consilium.europa.eu/pdf/en/12/st17/st17812.en12.pdf.

Danske Bank (2012). Danish support packages for the financial and corporate sectors. Available at http://danskebank.com/da-dk/ir/Documents/Presentations/2012/201203Danish-Support-Packages.pdf.

Danske Bank (2013). The Danske Bank Group Annual Report 2012. Available at http://www.danskebank.com/en-uk/ir/Documents/2012/Q4/Annualreport-2012.pdf.

Darvas, Z. (2011). A Tale of Three Countries: Recovery after Banking Crises. Bruegel Policy Contribution, 2011/19.

De Sousa, C., Wolff, G. B. (2012). A Banking Union of 180 or 91\%? Bruegel Blog, December 13, 2012.

Emerging Markets (2013). European Commission Worried About Bank "Ring-Fencing". Retrieved February 4, 2013 from http://www.emergingmarkets.org/Article/3150917/Economics-and-Policy/European-Commission-worried-about-bank-ring-fencing.html.

European Council (2012). Conclusions. European Council 13/14 December. Available at http://www.consilium.europa.eu/uedocs/cms_data/docs/pressdata/en/ec/134353.pdf.

Gerlach, S., Wolff, G. B. (2010). Banking and Sovereign Risk in the Euro Area. CEPR Discussion Paper, 7833.

Merler, S., Pisani-Ferry, J. (2012). Hazardous Tango: Sovereign-Bank Interdependence and Fnancial Stability in the Euro Area. Financial Stability Review, 16.

OTP Bank PLC (2012). Interim Management Report, First nine months of 2012 results. Available at https://www.otpbank.hu/static/portal/sw/file/121114_OTP_20123Q_e_final.pdf. Pisani-Ferry, J., Wolff, G. B. (2012). The Fiscal Implications of a Banking Union. Bruegel Policy Brief, 2012/02.

Pisani-Ferry, J., Sapir, A., Véron, N., Wolff, G. B. (2012). What Kind of European Banking Union? Bruegel Policy Contribution, 2012/12.

Reuters (2013). EU Executive Warns National Bank Supervisors over Discrimination. Retrieved February 4, 2013 from http://www.reuters.com/article/2013/02/04/us-eu-banksregulation-idUSBRE9130IT20130204.

Schäuble, W. (2013). Banking Union Must Be Built on Firm Foundations. Financial Times, 12 May. Available at http://www.ft.com/intl/cms/s/0/8bdaf6e8-b89f-11e2-869f00144feabdc0.html\#axzz2UsbusoE8.

Véron, N. (2011). Euro Area Banks Must Be Freed from National Capitals. Bruegel Blog, September 20, 2011. Available at http://www.bruegel.org/publications/publicationdetail/publication/611-euro-areabanks-must-be-freed-from-national-capitals/.

Véron, N. (2012). Europe's Single Supervisory Mechanism and the Long Journey Towards Banking Union. Bruegel Policy Contribution, 2012/06.

Véron, N., Wolff, G. B. (2013). From Supervision to Resolution: Next Steps on the Road to European Banking Union. Bruegel Policy Contribution, 2013/04. 
Wolff, G. B. (2012). A Sunset Clause for Europe's Banking Union. Bruegel Blog, November 7, 2012. Available at http://www.bruegel.org/nc/blog/detail/article/936-a-sunsetclause-for-europes-banking-union/.

Zettelmeyer, J., Berglöf, E., de Haas, R. (2012). Banking Union: The View from Emerging Europe. In Beck, T. (ed.). Banking union for Europe: Risks and Challenges. London: Centre for Economic Policy Research. 


\section{Appendix: SSM coverage of non-euro area EU member states ${ }^{20}$}

We use the extensive but not comprehensive The Banker database to estimate the percent of total banking assets covered by the Single Supervisory Mechanism (SSM) in non-euro area member states, should they decide to join. This database includes 1,097 bank holding companies and subsidiaries out of the 9,076 monetary and financial institutions standing in the EU at the end of 2012. ${ }^{21}$ Since the institutions not included are small, the database has a good coverage of the total banking assets in the EU, varying between 71 percent and 100 percent (Table 4).

Table 4: Coverage of The Banker Database of total assets in the national financial system Total consolidated assets ( $€$ millions, end of 2012)

\begin{tabular}{lrrr}
\hline Country & The Banker & ECB & Coverage \\
\hline Bulgaria & 38,884 & 40,604 & $96 \%$ \\
Czech Republic & 152,388 & 175,276 & $87 \%$ \\
Denmark & 889,069 & 932,590 & $95 \%$ \\
Hungary & 96,810 & 110,986 & $87 \%$ \\
Latvia & 25,076 & 27,019 & $93 \%$ \\
Lithuania & 22,779 & 22,855 & $100 \%$ \\
Poland & 268,833 & 318,368 & $84 \%$ \\
Romania & 75,072 & 84,094 & $89 \%$ \\
Sweden & $1,497,254$ & $1,647,740$ & $91 \%$ \\
UK & $8,080,806$ & $11,353,739$ & $71 \%$
\end{tabular}

Sources: ECB and The banker Database. Note: Data from the Danker Database relates to end 2012, while the ECB consolidated balance sheet data is for June 2012.

A drawback of this dataset is that it reports the total assets of the whole banking group for the headquarters, and not just the assets from activities in the country of the headquarters. This matters for countries in which there are headquarters of banks with cross-border activities, like the UK, Sweden and Denmark, but also for Hungary. Unfortunately, we could not separate the non-domestic assets from The Banker database. In our calculations, we relate the euro amount of assets of financial institutions to be covered by the SSM from The Banker database to total assets from the ECB. Luckily, the European Central Bank has an aggregate balance sheet data that has exactly the same coverage: "Domestic banking groups and stand alone banks, foreign (EU and non-EU) controlled subsidiaries and foreign (EU and non-EU) controlled branches". We therefore used this aggregate, which is consistent with The Banker database, though this does not include only domestic assets.

Another drawback of the dataset is that it does not include most branches, some larger branches are erroneously counted as subsidiaries, and it misses some small subsidiaries as well. Therefore, our estimates for the percent coverage by the SSM in the case of participation presented in Figure 1 of the main text and Figure 3 should be taken as the

\footnotetext{
20 This appendix was prepared by Carlos de Sousa.

${ }^{21}$ The 1,097 data is from the The Banker database, the 9,076 figures is from the European Central Bank: http://www.ecb.int/press/pr/date/2013/html/pr130121.en.html.
} 
minimum share of total assets that would be under the SSM if all non-euro area member states would decide to join.

From the Regulation, we used the following criteria to assess whether a financial institution will fall under the supervision of the ECB:

i. The total value of its assets exceeds $€ 30$ billion; or,

ii. The ratio of its total assets over the GDP of the participating member state of establishment exceeds 20 percent, unless the total value of its assets is below $€ 5$ billion; or,

iii. It is among the three most significant credit institutions in the participating member state, unless justified by particular circumstances; or,

iv. It is subsidiary or branch of a banking group headquartered in a euro-area country; or,

v. It is subsidiary or branch of a banking group headquartered in a non-euro area EU country.

Non-euro area EU countries may join the SSM and therefore we introduced criterion (v) as well.

Note that other institutions that are concluded to have a significant relevance with regard to the domestic economy, and institutions in which cross-border assets or liabilities represent a significant part of total assets, will also be covered by the SMM, but we did not incorporate these considerations. Also, all institutions for which public financial assistance has been requested or received directly from the EFSF or the ESM will be covered by the SSM, but such direct support has not yet been granted and, according to current legislation, non-euro area countries cannot benefit from the European Financial Stability Facility and European Stability Mechanism.

Figure 1 in the main text presents our results for the total coverage in case of all EU countries join the SSM, while Figure 3 decomposes the data of Figure 1 according to the roles of the different criteria detailed above. 
Figure 3: Percent of assets falling under the SSM in the case of participation and the percent of assets of EU banks subsidiaries: detailed results

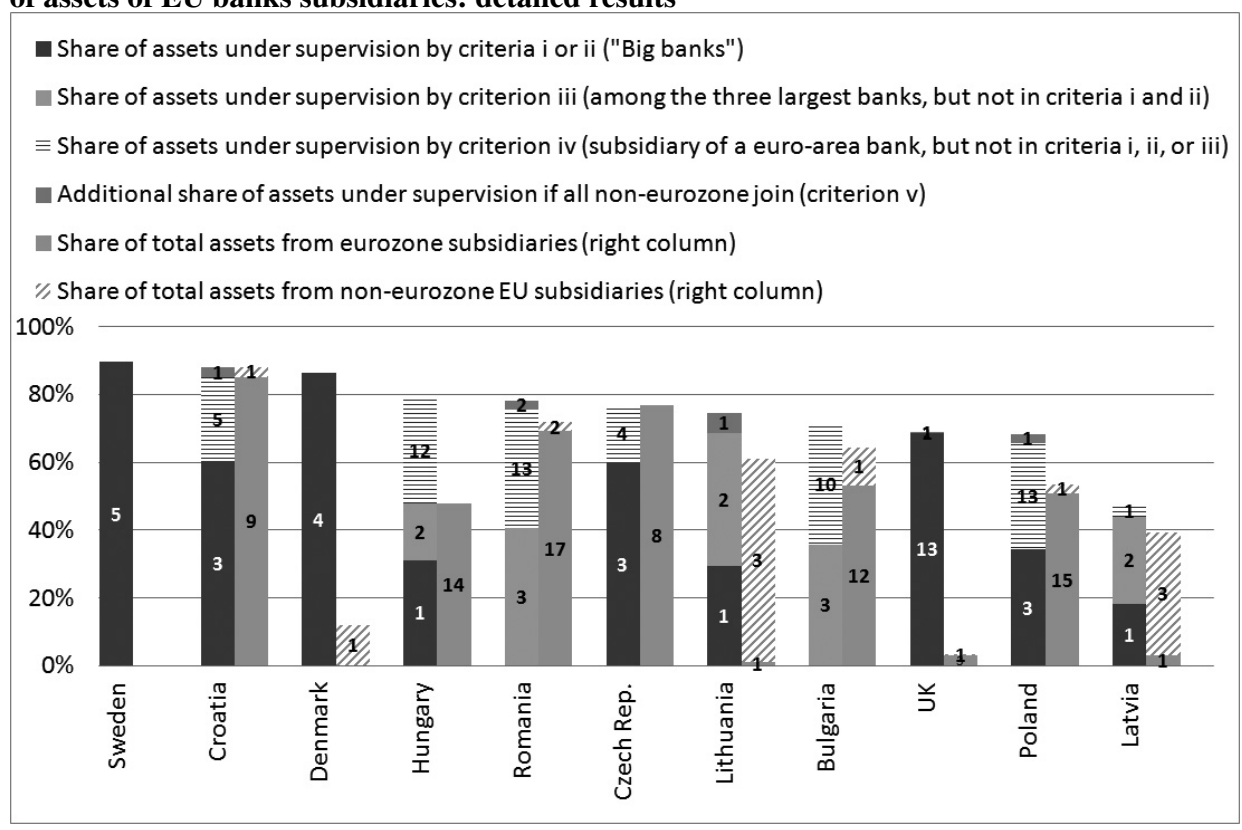

Sources: The Banker Database, ECB and Bruegel calculations

Note: This figure details the composition of the totals shown on Figure 1 of the main text. The left column for each country shows the coverage in the SSM (the criteria are detailed in this Appendix), while the right column shows the share of subsidiaries (and distinguishes between euro-area and other EU subsidiaries). Numbers over the bars indicate the number of banks that fall into each category. In the UK, there would be three banks under criteria iv and one additional bank if all non-euro area member states join, but their share is so small that it cannot be seen in the figure.

In order to check the precision of our estimates from The Banker database in the case of a particular country, we compared our results with the comprehensive dataset of the Hungarian Financial Supervisory Authority which includes all financial institutions, including branches (Table 5).

Table 5: Comparison of our estimates from The Banker database with the official data

\begin{tabular}{lccc}
\hline \multicolumn{1}{c}{ (Million euro; end-2012) } & $\begin{array}{c}\text { Hungarian Financial } \\
\text { Supervisory Authority }\end{array}$ & $\begin{array}{c}\text { The Banker } \\
\text { database }\end{array}$ & $\begin{array}{c}\text { The Banker database } \\
\text { combined with ECB } \\
\text { data on total assets }\end{array}$ \\
\hline Total assets & 118,297 & 96,810 & 110,986 \\
Assets under SSM & 91,690 & 87,853 & 87,853 \\
Total number of institutions & 435 & 23 & 23 \\
Number of institutions under SSM & 54 & 15 & 15 \\
Share of Assets under the SSM & $78 \%$ & $91 \%$ & $79 \%$ \\
\hline
\end{tabular}

Source of the Hungarian Financial Supervisory Authority data:

https://www.pszaf.hu/bal_menu/jelentesek_statisztikak/statisztikak/aranykonyv (in Hungarian) 
The two main reasons for the difference are that The Banker Database does not include (a) most of the branches and (b) smaller banks. As Table 5 shows, in the case of Hungary, the difference in assets under the SSM is not large and when we use total assets from the ECB and relate to it the assets to be covered from The Banker Database, the difference in the estimated share of assets to be covered by the SSM is small (78 percent versus 79 percent). For consistency with the data of other countries, in Figures 1 and 3 for Hungary we also use the euro value of the assets to be covered from The Banker database and total assets from the ECB. 